\title{
THE VENTURE CAPITAL SOLUTION TO THE PROBLEM OF CLOSE CORPORATION SHAREHOLDER FIDUCIARY DUTIES
}

\author{
SHANNON WELLS STEVENSON
}

\section{INTRODUCTION}

Over the past half century, both courts and legislatures ${ }^{1}$ have attempted to address the unique problems posed by shareholder relations in close corporations. ${ }^{2}$ Initially, the same law that governed public corporations also governed close corporations. ${ }^{3}$ Because of several significant differences between close and public corporations, however, this application of public corporation law frequently produced inequitable results. ${ }^{4}$ In response, courts began to fashion equitable solutions to the problems of close corporation shareholders, giving them greater freedom of contract, ${ }^{5}$ dissolution and buyout rights, ${ }^{6}$ and enhanced fiduciary duties. ${ }^{7}$ States have codified this unique treatment to varying degrees, and many have adopted special code sections governing close corporations. ${ }^{8}$

Copyright (C) 2001 by Shannon Wells Stevenson.

1. F. Hodge O’Neal, Close Corporations $§ 1.20$ (3d ed. 1987) ("Courts, like legislatures, increasingly have recognized the distinctive characteristics and needs of close corporations and have shown a growing willingness to treat these enterprises differently than publicissue corporations.").

2. For a discussion of the definition of "close corporation," see id. § 1.02.

3. Id. $\S 1.13$ (describing the advent of corporation statutes in the nineteenth century and their use by small enterprises).

4. $I d$.

5. See infra notes $31-38$ and accompanying text.

6. F. Hodge O'NeAl \& Robert B. ThOMpson, OpPression OF MinORITY SHAREHOLDERS $§ 7.13$ (2d ed. 1985) (stating that thirty-seven states list oppression of minority shareholders as grounds for dissolution).

7. See infra notes $39-55$ and accompanying text.

8. Tara J. Wortman, Note, Unlocking Lock-In: Limited Liability Companies and the Key to Underutilization of Close Corporation Statutes, 70 N.Y.U. L. REV. 1362, 1381-86 (1995) (identifying states that have adopted close corporation codes). Although many states provide special close corporation statutes, they are systematically underutilized by close corporations; thus, their benefits are lost. Id. at 1362 (reporting that approximately five percent of close corporations utilize close corporation statutes). 
Other states and many commentators dispute the need for this special treatment of close corporations, especially the imposition of greater fiduciary duties on shareholders. ${ }^{9}$ They argue that individuals who want this special treatment should choose alternative forms of business organization, such as limited liability companies (LLCs) or limited liability partnerships (LLPs). ${ }^{10}$ These forms are better suited to businesses with few shareholders, and many advantages formerly exclusive to corporations are now equally available to LLCs and LLPs. ${ }^{11}$ Additionally, they argue that the greater freedom of contract afforded close corporations should obviate the need for any other special treatment. ${ }^{12}$ Parties choosing the corporate form should consider whether it is best suited to their purposes and should use ex ante contracting to make any desired alterations rather than depend on ex post judicial remedies.

Recently, venture capitalists ${ }^{13}$ have emerged as a new breed of close corporation minority shareholder. Using the freedom of con-

9. See, e.g., Nixon v. Blackwell, 626 A.2d 1366, 1380-81 (Del. 1993) (declining to create special protections for close corporation shareholders); Frank H. Easterbrook \& Daniel R. Fischel, Close Corporations and Agency Costs, 38 STAN. L. REV. 271, 273 (1986) (analyzing critically "the argument that legal rules for closely held corporations should approximate those for partnerships").

10. Wortman, supra note 8, at 1362-65; see Easterbrook \& Fischel, supra note 9, at 301:

Because people select the organizational device in which to invest, at the margin the risk-adjusted returns must be the same. There is no basis for treating one form or one group of investors as favorites of the law, and there is every reason to treat both groups of investors as intelligent adults whose contracts should be enforced.

11. 1 Joseph W. Bartlett, Equity Finance: Venture Capital, Buyouts, RESTRUCTURINGS AND REORGANIZATIONS 36-52 (2d ed. 1995) (comparing proprietorships, general and limited partnerships, LLCs, business trusts, and other organizations); Larry E. Ribstein, Statutory Forms for Closely Held Firms: Theories and Evidence from LLCs, 73 WASH. U. L.Q. 369, 431 (1995):

Indeed, the LLC phenomenon could spell the end of the close corporation business form. Close corporations temporarily accommodated the corporate form to closely held firms while alternative forms were unavailable for tax and interstate recognition reasons. This accommodation has been imperfect in many ways. In particular, grafting close corporation governance arrangements onto a form with limited transferability of interests and no right of dissolution at will has forced the courts and legislatures to adopt an awkward and ad hoc oppression remedy in order to provide a right of exit. The LLC has made these makeshift devices unnecessary.

Wortman, supra note 8, at 1364-65 (arguing that limited liability company statutes represent the best alternative for close corporations). For a comprehensive discussion of the advantages and disadvantages of choosing the corporate form for a start-up company, see generally Joseph Bankman, The Structure of Silicon Valley Start-Ups, 41 UCLA L. REV. 1737 (1994).

12. See generally Easterbrook \& Fischel, supra note 9 (describing contractual solutions to close corporation problems).

13. A venture capital investment is characterized by the following factors:

(1) new technology, new marketing concepts, and new product application possibili- 
tract afforded close corporation shareholders to negotiate stock purchase and shareholder agreements, venture capitalists appear effectively to have resolved many of the traditional problems of close corporations. ${ }^{14}$ Their apparent success in solving close corporation problems seems to support the arguments against imposing enhanced fiduciary duties on close corporation shareholders, proving that even a minority shareholder can protect himself through ex ante contracting.

In Part I, I discuss the characteristics of close corporations that make application of general corporate law problematic, and I describe typical problems generated by this misapplication. I then describe two solutions employed by courts and legislatures-greater freedom of contract and enhanced fiduciary duties ${ }^{15}$ - and summarize the arguments for and against enhanced fiduciary duties, discussing current perspectives on the state of close corporation shareholder fiduciary duty law. In Part II, I demonstrate how the typical stock purchase and shareholder agreements utilized by venture capital firms solve many of the traditional problems encountered by close corporation shareholders. In Part III, I illustrate how the venture capital model could be used to improve typical close corporation shareholder relations and assess whether this model is a realistic model for other close corporation shareholders. I conclude that although some important differences exist between the venture capitalist and the typical close corporation shareholder, the success of the venture capital

ties; (2) a significant, although not necessarily controlling participation by the investors in the company's management; (3) investment in ventures staffed by people of outstanding competence and integrity...; (4) products or processes which have passed at least through the early prototype stage and are adequately protected by patents, copyrights, or trade secret agreements ( . . . where the information is "proprietary"); (5) situations which show promise to mature within a few years to the point of an initial public offering or a sale of the entire company ( . . "exit strategy"); (6) opportunities in which the venture capitalist can make a contribution beyond the capital dollars invested ( . . "value-added strategy").

1 BARTLETT, supra note $11, \S 1.1$, at 2 . This Note focuses on this traditional type of venture capital rather than later-round investments or buyouts of mature businesses.

14. Gordon Smith, Venture Capital Contracting in the Information Age, 2 J. SMALL \& EMERGING BUS. L. 133, 153 (1998) ("Conventional wisdom has it that lawsuits in the venture capital community are rare."); id. at 144 (stating that "reported cases involving disputes between venture capitalists and entrepreneurs are relatively rare").

15. Although public corporations generally elect to incorporate in Delaware, generating a standard corporate law for public corporations, the same is not true for close corporations. Most close corporations are incorporated in the state of their principal place of business. See FREDERICK D. LIPMAN, VENTURE CAPITAL AND JUNK BOND FINANCING § 6.04, at 163, 204-05 (1996) (presenting a venture capital agreement where a close corporation doing business in Pennsylvania is organized under Pennsylvania law). 
model weighs against the further development of judicially imposed fiduciary duties.

\section{THE FIDUCIARY DUTY OF ClOSE CORPORATION SHAREHOLDERS}

\section{A. Characteristics of Close Corporations and the Problems Posed by the Application of General Corporate Law}

Close and public corporations differ in ways that make general corporate law ill suited to close corporations. Although these differences tend to affect close corporation minority shareholders, majority shareholders also can be vulnerable.

The first major distinction between close and public corporations is that close corporations usually do not have separation of functions-the shareholders of a close corporation often serve as the directors or officers, providing the capital and managing the corporation. $^{16}$ Unlike public corporation shareholders, who have invested only a fraction of their capital, close corporation shareholders frequently depend on the corporation's success for their livelihoods. ${ }^{17}$ Thus, a minority shareholder in a close corporation is vulnerable to abuses of the majority's discretion, particularly with respect to the shareholder's employment or the distribution of dividends, which may be the minority shareholder's only source of cash from the corporation.

His dependence on the corporation, his lack of control, and the illiquidity of his shares thus pose problems for the minority shareholder. ${ }^{18}$ Unlike a public corporation shareholder who may sell his shares with ease at any time, the close corporation minority shareholder often will encounter substantial difficulty in disposing of his

16. E.g., Charles R.T. O'Kelley \& Robert B. ThOMpson, Corporations AND OTHER BUSINESS ASSOCIATIONS 453 (3d ed. 1999); Easterbrook \& Fischel, supra note 9, at 273-77; William S. Hochstetler \& Mark D. Svejda, Statutory Needs of Close Corporations-An Empirical Study: Special Close Corporation Legislation or Flexible General Corporation Law?, 10 J. CORP. L. 849, 853-56 (1985).

17. See, e.g., Donahue v. Rodd Electrotype Co. of New England, 328 N.E.2d 505, 514 (Mass. 1975) ("The stockholder may have anticipated that his salary from his position with the corporation would be his livelihood.").

18. O'KeLlEY \& THOMPSON, supra note 16, at 454. But see Easterbrook \& Fischel, supra note 9 , at 275-78 (disagreeing with the traditional idea of how share illiquidity harms shareholders, but identifying four "informational" ways in which "the lack of an active market for shares can injure investors in closely held corporations"). 
shares. ${ }^{19}$ This problem may be compounded because the shareholder often is bound agreement or statute to offer his shares to the corporation first. ${ }^{20}$ Thus, the shareholder may be trapped in the corporation, unable to exit or exercise control and possibly barred from receiving salary or dividends. ${ }^{21}$

Although many of these problems could be eliminated through ex ante contracting, ${ }^{22}$ another feature of the close corporation reduces the likelihood that such contracting will occur. Frequently, the shareholder relationship is preceded by other relationships, such as bonds of family or friendship. ${ }^{23}$ Because these relationships of trust exist, close corporation shareholders invest less in ex ante contracting, putting faith in the prior relationships to resolve corporate disputes. Often, parties incorporating close corporations are less sophisticated in business and legal matters, making them even less likely to engage in ex ante contracting. ${ }^{24}$

These unique characteristics generate several different scenarios that lead to litigation. ${ }^{25}$ The best known is "freeze-out." In this scenario, a minority shareholder is excluded from the management of the corporation. His exclusion prompts him to exit, forcing him to sell his shares to the majority or back to the corporation at an unfairly low price. ${ }^{26}$ A second scenario is the corporation's unequal treatment

19. O’NEAL, supra note $1, \S 1.22$.

20. Id. § 1.01 .

21. See, e.g., G\&N Aircraft, Inc. v. Boehm, 743 N.E.2d 227, 233 (Ind. 2001) (describing a situation in which a majority shareholder threatened to block dividends for three years); A. Richard M. Blaiklock, Note, Fiduciary Duties Owed by Frozen-Out Minority Shareholders in Close Corporations, 30 IND. L. REV. 763, 775-76 (1997) (describing the withholding of dividends as a common method of freezing out a minority shareholder).

22. For example, the parties could agree to guaranteed employment for a minority shareholder, or mandate a particular dividend policy. See infra notes 31-38 and accompanying text.

23. O'NEAL, supra note $1, \S 1.08$.

24. O'Kelley \& ThOMPSON, supra note 16, at 454; O'NeAL, supra note 1, § 1.21(5):

Yet, many participants in closely held corporations are "little people," unsophisticated in business and financial matters. Not uncommonly, participants in a closely held enterprise invest all their assets in the business with an expectation, often reasonable under the circumstances even in the absence of an express contract, that they will be key employees in the company and will have a voice in business decisions.

See generally Easterbrook \& Fischel, supra note 9, at 273-78 (discussing contractual arrangements in the close corporation setting).

25. See James M. Van Vliet, Jr. \& Mark D. Snider, The Evolving Fiduciary Duty Solution for Shareholders Caught in a Closely Held Corporation Trap, 18 N. ILL. U. L. REV. 239, 252-61 (1998) (describing typical problems faced by close corporation shareholders).

26. O'KELLEY \& THOMPSON, supra note 16, at 454-55 (illustrating how close corporation characteristics can lead to the freeze-out of a shareholder). 
of different shareholders. ${ }^{27}$ For example, the majority may approve the purchase of one shareholder's shares for a good or fair price, while declining to do the same for others. A third scenario generally can be identified as frustration of reasonable expectations-for instance, when a shareholder expects he will have a position as a director, as an officer or employee, or as the controlling shareholder, and the majority deprives him of that position. ${ }^{28}$ A fourth scenario may occur when one shareholder begins competing with the corporation in another business. ${ }^{29}$

Although the close corporation minority shareholder is uniquely vulnerable because of his lack of control and inability to dispose of his shares, controlling or majority shareholders also are vulnerable. Like the minority shareholder, the controlling shareholder may depend on the corporation for her livelihood. Although her shares may be more liquid than those of the minority shareholder because they carry control, they are still far less liquid than shares of a public corporation. The majority shareholder also may depend on the special expertise of the minority shareholder for the operation of the business, making the majority shareholder vulnerable to the minority shareholder's departure. Lastly, a shareholder who has a controlling percentage of shares, but not a majority, may be overpowered by minority shareholders and can be vulnerable to deadlock with respect to actions requiring supermajority approval. ${ }^{30}$

\section{B. The Contractual Freedom Solution}

These close corporation shareholder problems initially prompted courts to recognize greater freedom of contract because of the judicial belief that the source of the shareholders' problems was their inability to contract to restrict the broad discretion of directors. ${ }^{31}$ And indeed,

27. Van Vliet \& Snider, supra note 25, at 252-61.

28. Id.; see, e.g., Wilkes v. Springside Nursing Home, 353 N.E.2d 657, 661 (Mass. 1976) (describing how the plaintiff was voted out of his position as a director and officer); Johns $\mathrm{v}$. Caldwell, 601 S.W.2d 37, 39 (Tenn. Ct. App. 1980) (describing how a forty-five percent shareholder wished to restrict the sale of a ten percent shareholder's shares to another forty-five percent shareholder, thereby creating a majority shareholder).

29. See, e.g., Hagshenas v. Gaylord, 557 N.E.2d 316, 318 (Ill. App. Ct. 1990) (noting that a fifty percent shareholder established a competing travel agency); Ellis \& Marshall Assocs. v. Marshall, 306 N.E.2d 712, 713-15 (Ill. App. Ct. 1973) (noting that the minority shareholder solicited clients and employees of the plaintiff); J Bar H, Inc. v. Johnson, 822 P.2d 849, 854 (Wyo. 1991) (noting that the shareholder set up a competing meat processing business).

30. See infra note 33 and accompanying text.

31. J.A.C. Hetherington \& Michael P. Dooley, Illiquidity and Exploitation: A Proposed Statutory Solution to the Remaining Close Corporation Problem, 63 VA. L. REV. 1, 1 (1977); see 
contractual freedom does enable minority shareholders to reduce the likelihood of the scenarios described above. ${ }^{32}$

But this greater freedom of contract generated its own practical difficulty for close corporations. Minority shareholders previously subject to the discretion of overpowering majority shareholders now could create deadlock by vetoing any corporate action requiring minority shareholder approval. ${ }^{33}$ Some commentators advised that minority shareholders be given statutory buyout and dissolution rights to resolve this problem. ${ }^{34}$ Others observed that enhanced fiduciary duties were necessary to compensate for the shortcomings of contractual freedom, namely the failure of shareholders to utilize ex ante contracting. ${ }^{35}$ Many courts ${ }^{36}$ and a few legis-

DEL. CODE ANN. tit. viii, §§ 350-351 (1991) (permitting shareholder agreements that restrict the discretion of the directors and allow for exclusive shareholder governance); O'NEAL, supra note $1, \S \S 1.01,1.20$ (stating that "modern corporations' statutes permit close corporation participants to modify the traditional norms of corporate law that reflect the needs of large, publicly held corporations" and that "even before there was widespread legislation permitting corporations to depart from the statutory norm of unfettered director rule, courts began to move away from earlier decisions striking down shareholder agreements"); Hochstetler \& Svejda, supra note 16, at 907 ("All states that have enacted special close corporation legislation provide for shareholders' agreements ....”).

32. Hochstetler \& Svejda, supra note 16 , at 854 :

[T] he shareholders in a close corporation are in a better position than shareholders in a publicly held corporation to protect their investment in the corporation through the use of shareholders' agreements. Shareholders' agreements may allow shareholders to retain permanent positions as directors and officers, provide minority shareholders with veto power through provisions requiring unanimous agreement, permit restrictions on transferability of shares, and provide for the withdrawal of a shareholder through a buy-out of the withdrawing shareholder's investment or through dissolution of the corporation.

33. O'NEAL, supra note $1, \S 4.21$ (noting that "the presence of veto arrangements increases the chance that a deadlock will occur in the corporation's management which will paralyze the corporation and render it unable to conduct its affairs" and "may place an unscrupulous shareholder in a position to extort ... unfair concessions from other shareholders"); id. § 9.18 ("Legislatures and judges today recognize that the structure of intimate, illiquid close corporations requires some modification of the statutory norms. The increased freedom to contract concerning governance arrangements now permitted for participants in close corporations can lead to deadlock or stalemate for which the parties inadequately planned.").

34. See Hetherington \& Dooley, supra note 31, at 6 (proposing statutory buyout provisions).

35. See infra notes $56-68$ and accompanying text.

36. Wilkes v. Springside Nursing Home, Inc., 353 N.E.2d 657, 663 (Mass. 1976) (ruling for the plaintiff, a minority shareholder, on the ground that the majority shareholders did not show a "legitimate business purpose" for relieving him of his duties); Donahue v. Rodd Electrotype Co. of New England, 328 N.E.2d 505, 512 (Mass. 1975) (holding that shareholders in a close corporation owe each other the same fiduciary duties as partners owe others in a partnership). Some courts have extended fiduciary duties not only to majority or controlling shareholders, but also to minority shareholders. See, e.g., Smith v. Atl. Props., Inc., 422 N.E.2d 798, 803 (Mass. App. Ct. 1981) (holding that the minority shareholder's actions "were inconsistent with any rea- 
latures $^{37}$ responded to this "widespread failure of minority shareholders to use self-help" ${ }^{38}$ by imposing enhanced fiduciary duties on close corporation shareholders.

\section{The Enhanced Fiduciary Duty Solution}

In 1975, Massachusetts initiated the trend toward imposing enhanced fiduciary duties on close corporation shareholders in Donahue v. Rodd Electrotype Co. of New England. ${ }^{39}$ In Donahue, the seminal case on close corporation shareholder fiduciary duties, a minority shareholder challenged the corporation's decision to purchase the stock of a retiring director, Harry Rodd. ${ }^{40}$ Two of the three directorshareholders who approved the purchase (for $\$ 800$ per share) were Rodd's sons, who had declined in previous years to have the corporation purchase the plaintiff's stock for prices between $\$ 40$ and $\$ 200$ per share. ${ }^{41}$ Insisting that the fiduciary duties owed by close corporation shareholders to each other were the same as those owed by partners ("the duty of finest loyalty"), ${ }^{42}$ the Massachusetts Supreme Judicial Court required the corporation to give each shareholder "an equal opportunity to sell a ratable number of his shares to the corporation at an identical price."

Following Donahue, the Massachusetts courts wrestled with the scope of this equal opportunity doctrine, and in Wilkes $v$. Springside Nursing Home, Inc., ${ }^{44}$ the Supreme Judicial Court narrowed its scope, holding that shareholders could be treated differently for a legitimate

sonable interpretation of a duty of "utmost good faith and loyalty"'). See generally Blaiklock, supra note 21 (discussing the issue of minority shareholders' fiduciary duties to majority shareholders); J.A.C. Hetherington, The Minority's Duty of Loyalty in Close Corporations, 1972 DUKE L.J. 921 (describing the minority shareholders' duty of loyalty).

37. E.g., MinN. STAT. ANN. § 302A.751(1)(a)(2) (2001) (permitting a court to order any equitable relief that is "just and reasonable" when "the directors or those in control of the corporation have acted . . . in a manner unfairly prejudicial toward one or more shareholders in their capacities as shareholders, directors, or officers, or as employees of a closely held corporation"); N.D. CENT. CODE § 10-19.1-115 (2001) (same).

38. O’NEAL, supra note $1, \S 1.21(2)$.

39. 328 N.E.2d 505 (Mass. 1975). But see Robert A. Ragazzo, Toward a Delaware Common Law of Closely Held Corporations, 77 WASH. U. L.Q. 1099, 1104-05 (1999) (noting that the "fiduciary duty" imposed in Donahue is a misnomer because the duty "recognized in Donahue is really a duty to act fairly toward other shareholders").

40. Donahue, 328 N.E.2d at 508 .

41. Id. at 509-10.

42. Id. at 516 (quoting Meinhard v. Salmon, 164 N.E. 545, 546 (N.Y. 1928)).

43. Id. at 518 .

44. 353 N.E.2d 657 (Mass. 1976). 
business purpose if no alternative were available. ${ }^{45}$ In Wilkes, three shareholders, who together owned seventy-five percent of the corporation's shares, failed to reelect Wilkes, the fourth shareholder, to a position as a director and officer. ${ }^{46}$ Because Wilkes had reasonably expected to retain these positions based on the original understanding of all four shareholders, the court held that the majority could not exclude him unless they did so for a legitimate business purpose. ${ }^{47}$ Finding that Wilkes had been voted out because of the shareholders' disagreement with his legitimate voting decisions, the court determined that the majority had breached its fiduciary duty to Wilkes. ${ }^{48}$

Since Wilkes, Massachusetts continues to impose relatively strict fiduciary duties on close corporation shareholders, extending the duties even to minority shareholders. ${ }^{49}$ Although there is no consensus among the states about the scope of the fiduciary duties owed by close corporation shareholders to one another, ${ }^{50}$ the vast majority of state courts have held that heightened duties do exist. ${ }^{51}$

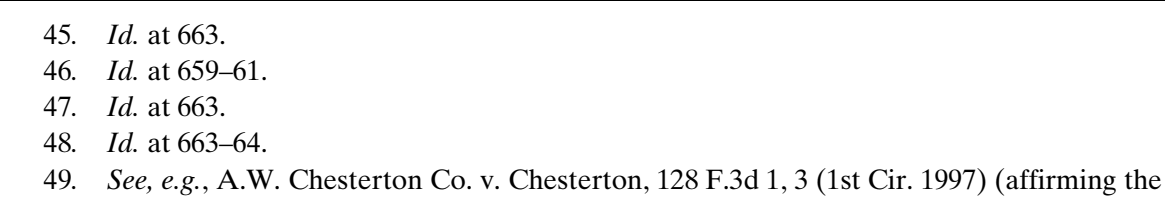
district court's judgment against a minority shareholder who attempted to transfer his stock to shell corporations); Zimmerman v. Bogoff, 524 N.E.2d 849, 853-54 (Mass. 1988) (affirming the trial court's judgment against the defendant shareholder on the ground of breach of fiduciary duty for reneging on his good faith agreement to pay equipment rent to the plaintiff shareholder's business); Smith v. Atl. Props., Inc., 422 N.E.2d 798, 803 (Mass. App. Ct. 1981) (affirming the trial court's judgment that held a shareholder liable for penalty taxes assessed against the corporation as a result of the shareholder's refusal to distribute dividends). See generally Blaiklock, supra note 21 (discussing the fiduciary duties of minority shareholders).

50. See L. Clark Hicks, Jr., Recent Decision, Fought v. Morris, 543 So. $2 d 167$ (Miss. 1989), 60 Miss. L.J. 425, 435-36 n.55 (1990) (listing states that apply a variety of different standards of fiduciary duties to majority and minority shareholders).

51. See, e.g., Rexford Rand Corp. v. Ancel, 58 F.3d 1215, 1220-21 (7th Cir. 1995) (holding that a shareholder continued to owe a fiduciary duty of loyalty to the corporation under Illinois law after he had been frozen out); Gay v. Gay's Super Markets, Inc., 343 A.2d 577, 582 (Me. 1975) (holding that majority shareholders did not breach their duty of good faith to a nonemployed minority shareholder by declaring low dividends and high salaries for themselves where legitimate reasons for doing so existed); Evans v. Blesi, 345 N.W.2d 775, 780 (Minn. Ct. App. 1984) (finding a breach of fiduciary duty by oppressive tactics when majority stockholders obtained the minority stockholders' resignations under coercion); Frank Lerner \& Assocs., Inc. v. Vassy, 599 N.E.2d 734, 738 (Ohio Ct. App. 1991) (recognizing a fiduciary duty owed by shareholders in a corporation to other shareholders, but nonetheless holding that the defendant minority shareholders did not breach that duty by notifying a corporate creditor that they would not be liable for future draws against the line of credit); Zidell v. Zidell, 560 P.2d 1086, 1089 (Ore. 1977) (holding that the fiduciary duty of majority shareholders toward minority shareholders, with respect to dividend policy, "is discharged if the decision is made in good faith and reflects legitimate business purposes rather than the private interests of those in control"); Fer- 
A few states, such as Minnesota, even have codified these enhanced fiduciary duties. ${ }^{52}$

In stark contrast to the majority view that supports these enhanced duties, a handful of states have declined to provide this special protection for close corporation shareholders. Foremost among these states is Delaware, which articulated this position in Nixon v. Blackwell. ${ }^{53}$ Other states, following Delaware, also have declined to impose stricter duties on close corporation shareholders. ${ }^{54}$ States are continuing to choose between the stricter fiduciary duties imposed in most jurisdictions and Delaware's refusal to provide special protection. ${ }^{55}$

\section{Arguments for and Against Enhanced Fiduciary Duties}

As described in the previous Section, essentially two approaches to the problem of close corporation shareholder fiduciary duties have emerged. The first favors enhanced duties and is followed by the majority of states, including Massachusetts. ${ }^{56}$ The minority of states, including Delaware, follows the contrary position. ${ }^{57}$

ber v. Am. Lamp Corp., 469 A.2d 1046, 1050 (Pa. 1983) (holding that a majority shareholder may act in his own best interest, but the shareholder's actions also must be in the best interests of the corporation); Nelson v. Martin, 958 S.W.2d 643, 649 (Tenn. 1997) (holding that the shareholders "were obligated to deal fairly and honestly with [their fellow shareholder] and could not act out of avarice, malice, or self-interest in violation of their fiduciary duty to him as a shareholder"); J Bar H, Inc. v. Johnson, 822 P.2d 849, 859 (Wyo. 1991) (applying a "fundamental duty of loyalty and fiduciary responsibility" to close corporation shareholders); O'NEAL, supra note $1, \S 9.21$ ("Differences as to the scope and meaning of the fiduciary duties under a Donahue standard do not detract from its widespread acceptance."); Hicks, supra note 50, at 435-36 n.55 (noting that most jurisdictions now follow the rule that controlling and majority shareholders owe a fiduciary duty to the minority shareholder in the context of a close corporation, but disagree as to the extent of the duty).

52. See supra note 37 and accompanying text.

53. 626 A.2d 1366, 1379-81 (Del. 1993) (rejecting "any special, judicially-created rules to "protect' minority stockholders of closely-held Delaware corporations"); see also Riblet Prods. Corp. v. Nagy, 683 A.2d 37, 40 (Del. 1996) (holding that the issue of the fiduciary duty owed to a minority stockholder did not arise in a case involving the minority stockholder's rights under an employment contract). But see Ragazzo, supra note 39, at 1101-02 (arguing that Delaware law provides largely the same protection as the "enhanced duties" in other jurisdictions provide).

54. See, e.g., Hunt v. Data Mgmt. Res., Inc., 985 P.2d 730, 732-33 (Kan. Ct. App. 1999) (adopting the holding of Nixon).

55. See, e.g., Hollis v. Hill, 232 F.3d 460, 466-69 (5th Cir. 2000) (choosing to apply partnership-like fiduciary duties for close corporation shareholders under Nevada law); Hunt, 985 P.2d at 733 (adopting the holding of Nixon); Lerner v. Lerner Corp., 750 A.2d 709, 720-22 (Md. Ct. Spec. App. 2000) (choosing to apply enhanced fiduciary duties for close corporation shareholders under Maryland law).

56. See infra notes 58-68 and accompanying text.

57. See infra notes $69-75$ and accompanying text. 
Proponents praise the application of partnership-like fiduciary duties, "[ $\mathrm{t}]$ he most recognized separate judicial treatment of close corporations, ${ }^{, 58}$ as the only way to protect "the trust and confidence essential to the size and manner of the enterprise and the inherent danger to minority interests. ${ }^{, 59}$ They insist freedom of contract does not provide sufficient protection because close corporation shareholders often cannot anticipate their contractual needs due to other relationships existing between them. ${ }^{60}$ Close corporation shareholders are more likely to be unsophisticated with respect to legal matters and to suffer from bounded rationality and foresight. ${ }^{61}$ The harmonious relationships necessary for a close corporation's success are easily destroyed by any number of circumstances - changes in the nature of the business, the death or incapacitation of a shareholder, the devise of a shareholder's interest, or a shareholder's decision to invest his talents or capital elsewhere. ${ }^{62}$ Because these changes cannot be foreseen, commentators argue, ex ante contracting is not sufficient to protect minority shareholders. ${ }^{63}$

Although some commentators believe the statutory right of a disgruntled minority shareholder to dissolve the corporation or to force it to purchase the minority's shares is sufficient, ${ }^{64}$ others, such as Professor F. Hodge O'Neal, further suggest that " $[\mathrm{t}] \mathrm{o}$ give adequate protection to minority shareholders frequently requires combining a greater readiness for judicial intervention with a remedy other than dissolution," ${ }^{65}$ and that permitting only dissolution rights will create an enterprise too unstable to attract investment. ${ }^{66} \mathrm{He}$ argues for man-

58. O’NEAL, supra note $1, \S 1.20$.

59. Id.; see also Van Vliet \& Snider, supra note 25, at 243 (" [W] vision or contract, or there is one but it is not valid or does not cover the particular situation, the judicially-developed shareholder-fiduciary concept may be the best available means to relief.").

60. O'NEAL, supra note $1, \S 1.21(2)$ ("Although most close corporation statutes validate special [contractual arrangements] designed to protect minority shareholders, few [provide] protection for minority shareholders who have failed to bargain for [contractual protection].").

61. Id.

62. Hetherington \& Dooley, supra note 31, at 2-3.

63. O'NEAL, supra note $1, \S 1.21(2)$ (stating that this additional protection is needed because "[m]inority participants in a close corporation may not anticipate dissension or oppression, and indeed may be unaware of their vulnerability, so that they frequently fail to bargain for adequate protection against mistreatment").

64. Hetherington \& Dooley, supra note 31, at 6 (arguing that the problem in close corporations is illiquidity, and that ex ante contracting and fiduciary duties are not sufficient solutions, but that the appropriate solution, rather, is permitting a minority shareholder to withdraw for any reason, selling his shares back to the corporation).

65. O’NEAL, supra note $1, \S 1.21(2)$ (praising Minnesota's statute, see supra note 37 ).

66. Id. 
datory legislation to protect shareholders who have failed to contract in advance or to contemplate the business form they are choosing for reasons of "naivete, bad legal advice, too [much optimism for] an emerging business, or concern over the cost of planning., ${ }^{, 67} \mathrm{He}$ supports

[a] statute stating that shareholders in a close corporation, just as partners in a firm, are to be held to strict fiduciary duties to each other in the operation of the business and in their dealings with each other ... . Similarly, legislation might be helpful that directed the courts, even in the absence of an express agreement, to protect the reasonable expectations of persons acquiring an interest in a close corporation, e.g., their expectation to participate in management or to be employed by the company. ${ }^{68}$

Commentators like Judge Frank H. Easterbrook and Professor Daniel R. Fischel explicate the contrary position; they believe "there are problems with pushing the analogy to partnerships too far," ${ }^{, 69}$ and they criticize the Donahue approach as an example of "a court ... unavoidably entwined in a dispute ... decid[ing] what the parties would have bargained for had they written a completely contingent contract." ${ }^{70}$ They argue it is a mistake to assume that all close corporation shareholders desire to be governed by partnership law and that imposing such duties on close corporation shareholders actually may defeat their expectations. ${ }^{71}$ The judicial role is to enforce parties' contracts, not to write contracts for them ex post.

Because people select the organizational device in which to invest, at the margin the risk-adjusted returns must be the same. There is no basis for treating one form or one group of investors as favorites of the law, and there is every reason to treat both groups of investors as intelligent adults whose contracts should be enforced. ${ }^{72}$

The relatively recent advent of alternative forms of business association, such as LLPs and LLCs, which combine favorable tax treatment and limited liability with partnership-like fiduciary duties

67. Id. $\S 1.21(3)$.

68. Id. $\$ 1.21(5)$.

69. Easterbrook \& Fischel, supra note 9, at 297.

70. Id. at 294 ("[I]t is most unlikely that they would have selected a rule requiring an equal opportunity for all.").

71. Id. at 298.

72. Id. at 301 . 
and freedom of contract, ${ }^{73}$ arguably bolsters this argument by eliminating the possibility that businesses are forced to incorporate to receive favorable tax treatment and limited liability. Easterbrook and Fischel note that although many close corporation shareholders may have chosen the corporate form for tax or liability purposes, courts cannot assume that the incorporators were "knowledgeable enough to incorporate ... [for those reasons] but ignorant of all other differences between corporate and partnership law." ${ }^{74}$ Thus, they believe the correct inquiry is not whether a close corporation resembles a partnership, but what the parties would have bargained for with no transaction costs.

The debate between these opposing viewpoints continues to play out as different states choose between these two theories of close corporation governance. ${ }^{76}$ Although many states have recognized enhanced fiduciary duties over the past twenty years, this approach continues to come under fire as states wrestle with the ambiguity inher-

73. See VGS, Inc. v. Castiel, No. C.A. 17995, 2000 WL 1277372, at*3-*4 (Del. Ch. Aug. 31, 2000) (holding LLC members owed a duty of loyalty to their fellow shareholder, even where the members acted in accordance with the LLC agreement and governing statutes).

74. Easterbrook \& Fischel, supra note 9, at 298.

75. Easterbrook and Fischel further observe that the ex post judicial imposition of fiduciary duties not only risks defeating the parties' expectations, but that certain differences between close and public corporations suggest that fiduciary duties actually should be stricter in public corporations. The director-shareholder in the close corporation is much more likely to feel the impact of his own poor business decision than a director in a large public corporation.

$[\mathrm{T}]$ he smaller number of participants in closely held corporations ensures that managers bear more of the costs of their actions and facilitates contractual arrangements between the parties to reduce the likelihood of self-dealing. The differences between publicly and closely held corporations, in other words, do not suggest unambiguously that the level of judicial scrutiny should vary or, if it does, in which direction.

Id. at 291-92. Lastly, they argue that even applying the same rules to public and close corporations will not necessarily yield the same results because of the different nature of the enterprises. $I d$. at 292-94. For instance, although preliminary merger negotiations may not be sufficiently material to a "reasonable" public corporation shareholder to require disclosure, they are likely to be material to a "reasonable" close corporation shareholder. Id. Thus, although no breach of duty occurs from failure to disclose in the former scenario, one may well be found in the latter, even though the court is applying the same standard. Id.; see also Jordan v. Duff \& Phelps, Inc., 815 F.2d 429, 431 (7th Cir. 1987) (comparing the duty to disclose merger negotiations in public corporations and close corporations).

76. Compare Donahue v. Rodd Electrotype Co. of New England, 328 N.E.2d 505, 512 (Mass. 1975) (applying partnership-like fiduciary duties to close corporation shareholders), and Rexford Rand Corp. v. Ancel, 58 F.3d 1215, 1218-19 (7th Cir. 1995) (same), with Nixon v. Blackwell, 626 A.2d 1366, 1376-77 (Del. 1993) (holding that there is no fiduciary principle requiring that stockholders be treated equally for all purposes), and Johns v. Caldwell, 601 S.W.2d 37, 45 (Tenn. Ct. App. 1980) ("[O]utside of the provisions of the by-laws and the written agreement between [the shareholders] no fiduciary or trust relationship existed between the [shareholders]...."). 
ent in ascertaining the terms for which the parties would have contracted. Both courts and legislatures have noted the vagueness and arbitrariness of applying these enhanced fiduciary duties in the close corporation context, ${ }^{77}$ describing the standards as "nebulous" "off-the-rack guess[es]" "79 at the intent of the parties. States and commentators criticize the use of a minority shareholder's "reasonable expectations" as a governing principle ${ }^{80}$ as well as the courts' failure to articulate comprehensible standards for "oppressive conduct."

These criticisms are most potent when courts apply these nebulous standards to reach results contrary to specific provisions of corporate law or in contravention of explicit contractual agreements between the parties. For instance, in Jordan v. Duff \& Phelps, Inc., the Seventh Circuit Court of Appeals imposed a fiduciary duty of disclosure on the corporation to inform an employee-minority shareholder of potential merger negotiations that could increase the future value of his shares. ${ }^{82}$ The employee had tendered his resignation for a date prior to the closing date of the merger and thus would not have benefited from the increased share value because he contractually was required to sell his shares back when his employment terminated. ${ }^{83} \mathrm{Al}$ though his

agreement was explicit that his status as a shareholder conferred no job rights on him.... the court [held] that the corporation had, as a

77. See, e.g., S.C. CodE ANN. § 33-18-400 cmt. 2 (Law. Co-op. 1990) ("No attempt has been made to define oppression, fraud, or unfairly prejudicial conduct. These are elastic terms whose meaning varies with the circumstances presented in a particular case, and it is felt that existing case law provides sufficient guidelines for courts and litigants.”); Kiriakides v. Atlas Food Sys. \& Servs., Inc., 541 S.E.2d 257, 264 n.18 (S.C. 2001) ("The courts of this state have only peripherally addressed the meaning of 'oppressive' or 'unfairly prejudicial' conduct.").

78. Hayes v. Olmsted \& Assocs., Inc., 21 P.3d 178, 181 (Or. Ct. App. 2001) ("The legislature has not defined 'oppression' for present purposes. ... [C]ourts must determine on a caseby-case basis whether the conduct complained of rises to the level of oppression, which we have variously described as 'nebulous,' and as lacking 'definitive definition."') (citations omitted) .

79. Duff \& Phelps, 815 F.2d at 436.

80. Kiriakides, 541 S.E.2d at 262-67 (providing a critique of the "frustration of reasonable expectations" approach and summarizing recent criticism in the literature of this standard).

81. Sandra K. Miller, Should the Definition of Oppressive Conduct by Majority Shareholders Exclude a Consideration of Ethical Conduct and Business Purpose?, 97 DICK. L. REV. 227, 229-30 (1993):

While business corporation statutes may attempt to provide certainty and clarity in the law to enhance the attractiveness of doing business, the definition of oppression has been left to judicial construction on a case-by-case basis. ... [T] he judicial development of a meaningful standard for defining oppressive conduct, apart from fraud or mismanagement, is a difficult task.

82. 815 F.2d at 439.

83. Id. at 436-37. 
matter of law, a duty ... to volunteer to the employee information about the corporation's prospects that might have led him to change his mind about quitting, although as an employee at will he had no right to change his mind. ${ }^{84}$

The employee explicitly had negotiated his employment rights with the corporation, leaving "nothing to the judicial imagination." ${ }^{85} \mathrm{Nev}$ ertheless, the court successfully defeated the expectations of both parties with the imposition of shareholder fiduciary duties.

Likewise, in Lerner v. Lerner Corp. ${ }^{86}$ a Maryland appeals court questioned whether a majority shareholder's decision to conduct a reverse stock split violated his fiduciary duties to the minority shareholder, despite the fact that the stock split was conducted in perfect accordance with corporate statutes. ${ }^{87}$ After spending several pages speculating about the appropriate test for a reverse stock split, the court concluded that, whatever the test was, the majority shareholder's reasons were sufficiently legitimate to justify the reverse split. ${ }^{88}$ Had the question of enhanced fiduciary duties not been on the table, this case would have reached the same outcome without the waste of judicial resources required to take it through trial to appeal. ${ }^{89}$

The Delaware model provides a simplicity that is yet another factor weighing against ex post judicial remedies. In Harrison v. NetCentric Corp. ${ }^{90}$ the Massachusetts Supreme Judicial Court was pre-

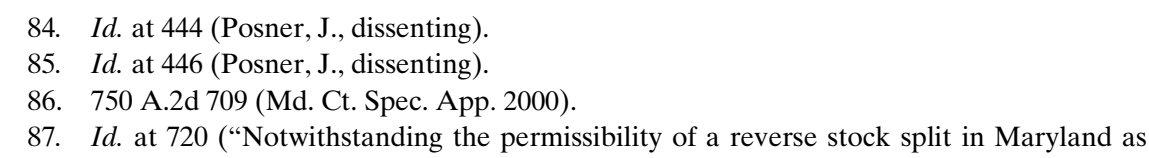
well as elsewhere, we must consider the duties of a majority stockholder to a minority stockholder in a closely held corporation ....").

88. Id. at 723 ("We note that ... regardless of whether we apply the test of business purpose or fairness, the evidence was sufficient to support . . . . a conclusion that there were reasons to effect the reverse stock split other than the desire, in and of itself, to oust a minority shareholder.").

89. Other examples of this problem proliferate. In Gunderson v. Alliance of Computer Professionals, Inc., 628 N.W.2d 173 (Minn. Ct. App. 2001), a minority shareholder who had "played a critical role in developing the company" informed the corporation he was leaving. Id. at 179. Threatened by this action, the corporation decided to remove him and followed its negotiated provisions for removal and buyout of his shares. Id. at 184. Even though the parties got exactly what they bargained for, the court ultimately remanded the case for findings on whether the plaintiff's reasonable expectations as a shareholder-employee were frustrated. Id. at 192-93. In A.W. Chesterton Co. v. Chesterton, 128 F.3d 1 (1st Cir. 1997), a minority shareholder followed the corporation's provisions for the sale of his shares. $I d$. at $4-5$. The corporation declined to buy them, and he sold them to other corporations, thus destroying the corporation's tax status. Id. at 3-5. Although his actions conformed to the law and to the agreements he had entered, the court enjoined him from selling his shares. Id. at 6-7.

90. 744 N.E.2d 622 (Mass. 2001). 
sented with a claim of breach of shareholder fiduciary duty in a close corporation. ${ }^{91}$ Because the corporation was subject to Delaware law, the court was able to dispose of the case in one sentence by enforcing the explicit contracts governing the shareholder's employment, instead of engaging in an agonizing inquiry into shareholder expectations.

Given the still-perplexing state of close corporation shareholder fiduciary duties, ${ }^{92}$ this Note looks to new evidence bearing on the application of these enhanced duties to ascertain whether the current majority rule, favoring enhanced duties, should continue to prevail. In the years since arguments first were articulated in favor of enhanced fiduciary duties, venture capital firms that have become minority shareholders in close corporations have been remarkably successful in avoiding the litigation scenarios frequently encountered by other close corporation shareholders. In the next two Parts, I illustrate the methods used by venture capitalists and assess what implications their success has for the future of close corporation shareholder law.

\section{The Venture CAPITAl EXAmple: Contractual Solutions TO CLOSE CORPORATION PROBLEMS}

To avoid the problems discussed in Part I that close corporation investors typically encounter, venture capital firms have seized the freedom of contract available to close corporation shareholders to develop stock purchase, shareholder, and employment agreements. ${ }^{93}$ Provisions in these agreements preserve the power of the minority investor to control the corporation, provide him with an exit strategy

91. Id. at 625 .

92. A further argument against attempting to apply the same body of law differently to close and public corporations is that rules evolve based on close corporations, which constitute the vast majority of corporations, and are then applied to public corporations, producing odd results. See Wortman, supra note 8, at 1379-81 ("If a statutory rule is interpreted in the case of the close corporation, the applicability of the interpretation to the public corporation becomes unclear.").

93. See Douglas G. Smith, The Venture Capital Company: A Contractarian Rebuttal to the Political Theory of American Corporate Finance?, 65 TENN. L. REV. 79, 87-89 (1997):

One salient example of shareholders exercising a large amount of influence over the governance and management of companies is found in the venture capital industry. Venture capital investment companies often negotiate rights that give them actual or potential control over the companies in which they invest-their "portfolio companies." Furthermore, venture capitalists also constrain managerial excesses through mechanisms other than the exercise of actual or potential control, such as contractual provisions that limit the activities of management ... . Perhaps such methods of control could be extended more widely. 
when necessary, and ensure that he is able to receive cash from the business in accordance with his expectations. Through these provisions, venture capital firms thus avoid the litigation scenarios encountered by typical close corporation shareholders and the need for ex post imposition of fiduciary duties. ${ }^{94}$

\section{A. Control}

Venture capital firms contract for a variety of rights that permit them to exercise varying degrees of control over the companies in which they invest. Many times this control is not absolute-it may exist only with respect to certain decisions or may be exercisable only under defined circumstances.

1. Board Representation and Access to Information. Securing seats on the board "is one of the most significant mechanisms through which venture capitalists exercise control over management of their portfolio companies." ${ }^{\circ 5}$ Although the investor typically will not contract for a majority of seats on the board (and thus will avoid the legal duties of a majority shareholder), he frequently will obtain enough seats for veto power ${ }^{96}$ by designating particular individuals to be elected to the board or by specifying how representation is to be allocated among the different shareholders. ${ }^{97}$ For instance, the agreement may provide:

The Stockholders agree to vote their shares ... and otherwise to use their best efforts ... to set and maintain the number of directors of the Company at no more than six and to elect and maintain as members of the Board of Directors: (i) two designees of [the investors]; (ii) two designees of [the founders]; and (iii) two persons who are officers of the Company and who are approved as directors by [the investors and the founders]. In the event of any vacancy on the Board of Directors, each stockholder covenants and agrees that it shall vote a sufficient number of shares of Voting Stock in accor-

94. It appears that some venture capitalists even disdain the ex post use of fiduciary duties. See 1 BARTLETT, supra note $11, \S 9.2$ ("[A]ny board member has an assortment of 'fiduciary' duties, a phrase that, once appearing in a judicial opinion, usually takes on a precise legal meaning, that is, recovery by the plaintiff."). See generally PAULINA BORSOOK, CYBERSELFISH (2000) (describing the libertarian bent of the high-tech industry, which constitutes much of venture capitalists' portfolios).

95. Smith, supra note 93, at 108.

96. Id. at 108-09.

97. 1 BARTLETT, supra note $11, \S 10.11$. 
dance with the procedure described above in order to fill such a vacancy. ${ }^{98}$

This provision ensures that the investors approve four of the six directors and directly elect two of the directors, giving the investors a strong voice on the board and veto power, if not direct control of the company. This veto power often is accompanied by a provision that flips control to the investors if the company is underperforming. ${ }^{99}$ Further, the investors may require that the company's articles be amended to provide that the investors may replace a director they elected at any time..$^{100}$ Thus, if the investors are not pleased with the conduct of a renegade director who begins to take the position of the founders against the investors, they immediately may replace her with another director more sympathetic to their wishes.

Alternatively, an investor merely may bargain for the right to attend the meetings of the board of directors and exert his influence through other avenues. ${ }^{101} \mathrm{He}$ may elect to be an "honorary" or "advisory" director who participates in board meetings but is not able to vote. ${ }^{102}$ Similarly, "[v]enture capitalists often include provisions that require management to provide them with more detailed and continuing information concerning the companies in which they invest than would otherwise be required," operating statements, budgets, access to the company's premises, and informational documents created by management for the investors. ${ }^{104}$

98. LIPMAN, supra note $15, \S 6.04$, at $256-57$.

99. 1 BARTLETT, supra note $11, \S 9.2$ :

[The agreement] may provide for a control "flip," meaning that the investors are content with a minority of the board as long as everything is going well; they succeed to outright control of the board when and as the company gets in trouble, allowing them to tie a can to the founder. Control flip can occur when benchmarks are not met or for more serious reasons, such as the violation of negative covenants in a Stock Purchase Agreement.

100. LIPMAN, supra note $15, \S 6.04$, at 220.

101. Heather M. Stone, The Structure of Venture Capital Financings: Stock Purchase Agreement $\$ 5.11$ (Sept. 29, 1999) (unpublished manuscript, on file with the Duke Law Journal).

102. 1 BARTLETT, supra note $11, \S 9.2$.

103. Smith, supra note 93, at 117.

104. Stone, supra note 101 (manuscript $\S 5.01$ ). One last measure by which the investors may secure spots on the board is by adopting a cumulative voting system that allows shareholders to cast all their eligible votes for all new directors toward one particular director. However,

[c]umulative voting is a clumsy way of ensuring board representation because it depends on the accidental fallout of numbers of shares, which can change over time, versus the number of directors standing for election, a number which can also be changed by the parties in control; it is not, accordingly, a popular charter provision, 
Because one common problem encountered by minority shareholders is deprivation of access to company information, the typical close corporation shareholder likely would benefit from such provisions. ${ }^{105}$

2. Voting Requirements on Special Issues. Shareholder agreements also may contain detailed voting requirements for significant issues. Thus, even if the investors do not comprise a majority of the board, they in fact may control decisions on issues as important as the appointment and compensation of officers, or the approval of mergers and consolidations. ${ }^{106}$ Investors also may restrict the company from taking certain actions without their approval. ${ }^{107}$ For example, the stock purchase agreement may provide that:

Prior to the commencement of each fiscal year ... , [the Company must] prepare and submit to, and obtain the approval of the [investors] of . . . monthly capital and operating expense budgets, cash flow projections, profit and loss projections, and a business plan. The Company shall not enter into any activity or make any expenditure not envisioned by the budget and business plan. ${ }^{108}$

Thus, an investor without the bargaining power to demand that the company take certain actions nonetheless may be able to secure veto power over certain corporate actions of particular concern to him. ${ }^{109}$ These voting agreements can be both detailed and extensive, permit-

the better practice being to organize the allocation of board seats in a contract among the shareholders.

1 BARTLETT, supra note $11, \S 4.11$.

105. E.g., Hollis v. Hill, 232 F.3d 460, 462 (5th Cir. 2000) (describing how a fifty percent shareholder prevented the other fifty percent shareholder from receiving any information about the corporation); Hayes v. Olmsted \& Assocs., Inc., 21 P.3d 178, 180 (Or. Ct. App. 2001) (holding that majority shareholders oppressed a minority shareholder by, inter alia, "refusing to provide information concerning bonuses and salaries").

106. 1 BARTLETT, supra note $11, \S 9.2$ ("The [stockholder agreement] often unbundles the macro-question of control and allocates the parts separately, across a spectrum of issues and across a period of time. Thus, it may provide that the investors may retain control over certain core questions - management compensation, for example, and not others.").

107. Investor approval can be required for, inter alia, conducting a merger, consolidation, or other disposition of control or assets; conducting any business with an affiliate of the company; changing the nature of the business; redeeming or purchasing outstanding shares; amending the company's articles or by-laws; altering or changing the rights of the investors' stock; creating a new series of stock having preference over or equal with the investors' stock; taking any action that would result in the taxation of the investors; issuing any new stock except according to the employee stock option plan; or adopting or amending employee benefit plans for key employees. LIPMAN, supra note $15, \S 6.04$, at 203-04, 221-22.

108. Id. $\S 6.04$, at 201-02 (emphasis added).

109. O'NEAL, supra note $1, \S 4.21$. 
ting the investor to exercise substantial control over almost any matter of significance to the future of the company and his stake in it.

Although veto provisions can be useful tools, "they do not enable minority shareholders to affirmatively determine corporate policy," 110 and they "may place an unscrupulous shareholder in a position to extort (as a condition of approval of beneficial corporate action) unfair concessions from the other shareholders." Another major problem with veto provisions is deadlock. When a minority shareholder effectively stops the corporation from taking needed action, dissolution may be the only remedy. Venture capital investors eliminate this gloomy possibility by including tie-breaker provisions in shareholder agreements, which provide for a method to resolve such a standstill. Tie-breakers may include the appointment of provisional directors or compulsory arbitration. ${ }^{112}$

3. Restrictions on Managerial Self-Dealing. One of the most practical uses of voting agreements and veto provisions is to enable the minority shareholder to contain potentially abusive conduct by majority shareholders. ${ }^{113}$ Agreements can prevent the majority shareholder from directing the corporation's activity to favor her interest, for instance, by entering the corporation into transactions with other corporations owned by the majority shareholder. Thus, "investment contracts between management and venture capitalists often contain a variety of covenants against managerial self-dealing, including limits on the sale of stock; payment of dividends; and loans to and repurchases of stock from insiders." ${ }^{\text {114 }}$ Such provisions limit the ability of an abusive majority shareholder to siphon money away from the company and its minority shareholders. ${ }^{115}$

4. Control over Managerial Compensation. In addition to exercising control over a shareholder-officer's extracurricular self-dealing conduct, the investors also may retain some control over an officer's day-to-day business decisions and influence on corporate policies.

110. Id.

111. Id.

112. 1 BARTLETT, supra note $11, \S 10.14$.

113. Smith, supra note 93, at 104 ("The influence that venture capitalists seek to exercise over management extends beyond mere board representation.... In addition to obtaining a voice on the board of directors, venture capitalists often seek protection through restrictive covenants that constrain the behavior of managers.").

114. Id. at 112 .

115. LIPMAN, supra note $15, \S 6.04$, at 203; Stone, supra note 101 (manuscript $\S 5.08$ ). 
The investors may have exclusive or partial power to appoint ${ }^{116}$ or remove high-ranking officers, or they may exert influence through control over managerial compensation. ${ }^{117}$ Control also may be used to create compensation packages that link the manager's compensation with the financial success of the company, thus aligning shareholder and manager interests. ${ }^{118}$

Employment agreements with key personnel are another tool used to ensure that a firm can retain key employees and that a minority shareholder will not be abandoned by a majority shareholder who elects to take his special knowledge or contacts elsewhere. ${ }^{119}$ This is particularly significant in venture capital investments because "the unseasoned firm is so dependent on critical people, it is important to tie those employees - the key ones at least — to the company as tightly as possible." 120

Investors also may use the employment agreement as a source of power to discontinue an employment relationship that has become inconsistent with the corporation's course. Many courts apply strong notions of fiduciary duties to preserve an employment relationship between shareholders, and the judicial trend is toward finding obligations of continued employment in the absence of a contract. Shareholders thus must consider contractually limiting an officer's right to continued employment. ${ }^{121}$

116. LIPMAN, supra note $15, \S 6.04$, at 220 ("The two directors elected by the [investors] shall have the sole and exclusive right to appoint, remove and re-appoint from time to time the Chief Executive Officer of the corporation.”); Smith, supra note 93, at 133.

117. Smith, supra note 93, at 114 ("[V]enture capital contracts often contain provisions allowing investors to control managerial compensation through a specific board veto over compensation, for example.").

118. Id. at 154 .

119. LIPMAN, supra note $15, \S 6.04$, at 225-33; Stone, supra note 101 (manuscript at Stock Purchase Agreement, Exhibits E, F).

120. Pulsifer v. Bitflow, Inc., No. 97-4508, 2001 Mass. Super. LEXIS 30 , at $* 15-* 16, * 42$ (Mass. Super. Ct. Jan. 26, 2001) ("BitFlow's success, in the short and long run, thus is directly and solely dependent on the continued labor and creativity of its key employees."); 1 BARTLETT, supra note 11, § 10.17; Clinton RiChaRdson, GROWTH COMPANY GUIDE 2000, at "Think Capital" (2000) (describing "the brain power of key employees" as "very important to prospective investors"), available at http://www.growco.com/gcgframe.htm (on file with the Duke Law Journal).

121. 1 BARTLETT, supra note $11, \S 10.17$ :

Courts in important commercial states are increasingly prepared to hold that something like partnership principles govern the relationship of the key players in a closely held company. In the absence of an agreement, this mind-set imports notions of equality and collegiality. If equity sweetens the employment relationship, the board may find a founding employee difficult to shed; partners can be fired only if their original agreement so provides. This possibility is reinforced by another emerging 
Lastly, the employment agreement can ensure that when an employee does leave, he is not able to injure the corporation through competition with it or by disclosing its proprietary information. ${ }^{122}$ Nondisclosure and non-compete agreements are particularly important for venture capital investors because frequently their portfolio companies are developing new technology. ${ }^{123}$

5. Rights of First Refusal. One last item of concern for minority investors is the preservation of the control they have contracted to ensure. To retain their percentage ownership, they must preclude the possibility that new shareholders will gain possession of existing or new stock, thus diluting the investors' percentage ownership. The shareholders' agreement may provide for several restrictions on how existing shareholders may transfer their shares and on how and when the company may issue new stock. To dispose of her shares, an existing shareholder first may have to offer them to the company and then to the investors or shareholders generally. ${ }^{124}$ This requirement prevents the exiting shareholder from passing power into unapproved hands. Likewise, the company may be required to offer the right to purchase new issues of shares to the investors before offering them elsewhere, ${ }^{125}$ or new issues may require the approval of the minority shareholders. ${ }^{126}$

trend-the tendency of courts to find or imply obligations of continued employment even in the absence of a contract to that effect.

O'NEAL, supra note $1, \S 9.21$ ("A particularly litigious area has been whether a partnership-like fiduciary duty prevents the termination of a shareholder/employee in a close corporation.").

122. 1 BARTLETT, supra note $11, \S 10.20$ (observing that an employment agreement "specifies salary and other benefits, of course, but .... [also] deals with control of the company's future and protection of vital assets, including the people who possess the intellectual property which is the backbone of many a start-up firm").

123. See id. $\S 10.30$ ("The flight of the scientific brains of the company into the arms of a competitor can be a death sentence.").

124. See id. $\S 4.9$ ("The provisions usually contemplate a repurchase by the company (if the company so elects) at either a price fixed in advance, at a price varying according to a formula (i.e., book value or an earnings multiple), at a price that matches the price offered by a third party or at 'fair value."'); LIPMAN, supra note $15, \S 6.04$, at 253-55:

If at any time any of the Current Holders wishes to sell all or any part of the Current Holder Shares owned by him, [he] shall submit a written offer to sell such Current Holder Shares to the Company on terms and conditions, including price, not less favorable to the Company than those on which [he] proposes to sell such Shares to any other purchaser.

125. LIPMAN, supra note 15, § 6.04, at 198 (section 7.4 of Venture Capital Agreement); Stone, supra note 101 (manuscript $\$ 5.02$ ).

126. See supra note 107 and accompanying text; see also Smith, supra note 93, at 119 ("In order to protect their ownership of the companies in which they invest, venture capitalists often 
These rights are "significant element[s] of governance in closely held corporations, important to ensure that stock [does] not fall into the hands of strangers without an opportunity in the company (or the remaining shareholders) to buy back some or all of the shares." ${ }^{127}$ Without them, the shareholders may be forced to deal with unanticipated shareholders with different goals. Shareholder agreements routinely provide for the company's repurchase of shares upon a shareholder's death, retirement, or incapacity, thus eliminating the problem of a shareholder's heirs disrupting the corporation's operations. $^{128}$

\section{B. Exit Strategy}

A primary point of negotiation in securing venture capital investment is the investor's concern with an exit strategy. ${ }^{129}$ Investors have devised numerous ways to recapture their capital from the corporation. Although a typical close corporation investor may not anticipate a future desire to recover his capital, these provisions reduce the necessity of relying on judicial remedies such as buyout or dissolution $^{130}$ and ensure that the investor is not trapped in the corporation if the majority decides to transfer its shares to another party.

1. Drag-Along. A drag-along provision requires that if some of the investors decide to sell their shares in the company, they may require the other stockholders to sell their shares on the same terms. ${ }^{131}$ This provision reduces one of the major illiquidity problems associated with a minority shareholder's shares. ${ }^{132}$ Normally, a minority

\footnotetext{
negotiate provisions forbidding all new issues of stock unless the issuance is approved by all, or some supermajority, of the shareholders.")

127. 1 BARTLETT, supra note $11, \S 4.9$.

128. O'NEAL \& THOMPSON, supra note $6, \S 9.03$.

129. LIPMAN, supra note $15, \S 2.01$ (f), at 44 ("All investors in privately-held companies want an 'exit strategy' ....").

130. O’NEAL, supra note $1, \S 1.21$.

131. LIPMAN, supra note $15, \S 6.04$, at 257 :

The [stockholders] agree to join at any time in any agreement to which the [investors] are parties at any time providing for the sale of the capital stock of the Company to any third party under which the [stockholders] will sell [their] [s] hares to such third party on the same terms and conditions ... as those terms and conditions under which [the investors] agree to sell their shares of the [Company's stock].

132. Cf. 1 BARTLETT, supra note $11, \S 10.15$ ("The ability of the majority to 'drag along' potentially dissident shares in the sale of the entire company can be, in the appropriate circumstances, economically useful as an alternative method for forcing complacent co-investors to cooperate in an exit strategy.").
} 
shareholder who wishes to exit a corporation is faced with a serious dilemma-even if there were a market for his shares, few would want to buy a noncontrolling interest in a corporation that a current shareholder is trying to leave. ${ }^{133}$ By forcing the other stockholders to sell as well, the minority investor is more likely to find a purchaser for the shares because he can guarantee the purchaser a control interest. This provision is particularly useful in the venture capital setting, when the investors may be willing to accept a purchase offer, but the founders, who are more attached to the business, want to hold out for a better offer. ${ }^{134}$

2. Tag-Along. The tag-along provision anticipates another likely scenario in which the minority shareholder receives the proverbial short end of the stick-when a majority shareholder sells her shares for a control premium, excluding the minority from any benefit in the sale and abandoning the minority in a corporation with an unanticipated majority shareholder. ${ }^{135}$ To remedy this scenario, the venture capital firms negotiate for a tag-along provision:

If at any time any of the [stockholders, excluding the investors,] wishes to sell any shares owned by him ... to any person or entity other than one or more of the Investors, . . . each of the Investors shall have the right to offer for sale to the Purchaser, as a condition of such sale by the Selling Party, at the same price per Share and on the same terms and conditions as involved in such sale by the Selling Party, the same proportion of the Shares owned by the Investor as the proposed sale represents with respect to said Shares then owned by such Selling Party. ${ }^{136}$

133. O'NeAL \& THOMPSON, supra note $6, \S 2.15$ (describing how the difficulty a minority shareholder faces in disposing of his shares often results in a squeeze-out); Easterbrook \& Fischel, supra note 9 , at 275 .

134. 1 BARTLETT, supra note $11, \S 10.15$ :

$[\mathrm{T}]$ he founders, controlling enough stock to block a corporate reorganization, will often want to hold the company as an independent vehicle in order, for example, to protect their employment or (more frequently) because their inflated expectations suggest that, if the investors will only be patient for another two or three years, a much greater payoff is in store. The cash investors, surmising the founders are infatuated with their own company, disagree; given the time value of money, the investors may want to realize on their investment as soon as it becomes possible to dispose the company in a merger.

135. O’NEAL \& THOMPSON, supra note $6, \S 4.01$ (describing sale of control by the majority shareholder).

136. LiPMAN, supra note 15, § 6.04, at 255; Stone, supra note 101 (manuscript at Stock Purchase Agreement, Exhibit B). 
Thus, the minority shareholder is able to claim a portion of the control premium. ${ }^{137}$

\section{Access to Cash}

In addition to guaranteeing an exit strategy that will enable them to recover cash from the corporation at the termination of their investment, minority investors also are interested in preserving their access to available cash during the course of the investment. For venture capitalists, the primary way to access this cash is through dividend provisions, ${ }^{138}$ for many other minority investors, the most significant cash stream will be salary received from employment by the corporation. ${ }^{139}$

Various provisions can ensure the payment of dividends. The investors' stock may be entitled to cumulative dividends, which grow when not paid and which prohibit the payment of dividends on common stock until all of the dividends on the preferred stock have been paid. ${ }^{140}$ Failure to pay dividends may result in increased voting power

137. Two other ways in which venture capitalists preserve the liquidity of stock are through the liquidation preference, redemption, and conversion features of preferred stock and through registration rights. The liquidation preference of preferred stock ensures that in a liquidation or dissolution of the corporation, the investors will receive a guaranteed amount for their shares and dividend accumulations before any assets of the corporation are distributed to the other shareholders. LIPMAN, supra note 15, § 6.04, at 210-11; Stone, supra note 101 (manuscript at Term Sheet 2). The stock's liquidation preference guarantees the investors a minimal amount of recovery if the corporation fails.

Preferred stock also often carries some form of redemption right, requiring the company to repurchase the shares for a specified price after a certain time period. 1 BARTLETT, supra note 11, § 9.13; LIPMAN, supra note $15, \S 6.04$, at 222; Smith, supra note 93, at 124-25; Stone, supra 101 (manuscript at Term Sheet 2). Like the liquidation preference, this ensures the investor a minimal recovery on his investment. The redemption date may be specified by date or by the occurrence of certain events, such as the company's failure to maintain a certain debt/equity ratio or to achieve certain revenues. LIPMAN, supra note $15, \S 6.04$, at 222-23.

Registration rights are a final way in which investors may liquidate their investment in the company. These rights permit the investors to demand that the officers take the company public ("demand rights"), Stone, supra note 101, Stock Purchase Agreement, at Exhibit A, or that, if the company decides to go public, the investors' shares will be included in the initial public offering ("Piggy Back Rights"), LIPMAN, supra note 15, § 6.04, at 182-85 \& n.42.

Although these provisions are extremely important to the venture capitalist, they have less salience for the typical minority close corporation shareholder, who likely cannot demand preferred stock and is less concerned with the prospect of taking the company public. See infra notes $189-90$ and accompanying text.

138. Smith, supra note 93 , at $124-25$.

139. See 1 BARTLETT, supra note $11, \S 10.22$ ("After the employee's salary and duties have been settled, counsel may tend to relax ....").

140. LIPMAN, supra note 15, § 6.04, at 210 (section 1(a) of Exhibit A) (providing for cumulative dividends). 
or board representation for the minority shareholders. ${ }^{141}$ Because "the most frequently used squeeze-technique is the withholding of dividends," 142 these provisions are essential for preserving the minority investors' access to cash.

Another major concern for the minority shareholder-employee "is that those in control will prefer themselves when distributing earnings. Any system that distributes profits in part through salary presents this danger." ${ }^{143}$ The minority shareholder-employee runs the risk both that the majority may declare an unfairly high salary for itself and an unfairly low salary for the minority shareholder-employee. Employment and compensation agreements provide a necessary prophylactic against this situation. They enable a minority shareholder to ensure continued employment and salary levels both for himself and for the majority. By obtaining veto power over the majority's ability to alter his employment agreement, the minority shareholder can ensure that the initial employment agreements remain in effect, consistent with his expectations. Because the termination or undercompensation of a minority shareholder-employee is one of the most litigated scenarios and typically calls for an ex post fiduciary duty remedy, a shareholder-employee probably can benefit the most from establishing terms of employment and termination of employment. ${ }^{144}$

\section{Application OF THE Venture CAPITAl Model to THE TYPICAL CLOSE CORPORATION SHAREHOLDER}

The investment agreements used by venture capital firms appear successful at minimizing the potential for litigation and maximizing the security of the minority investor's position in the management of the corporation. ${ }^{145}$ This Part uses recent cases to illustrate the poten-

\footnotetext{
141. Id. § 2.01(d), at 41; O’NEAL \& THOMPSON, supra note $6, \S 9.06$.

142. O'NEAL \& THOMPSON, supra note $6, \S 9.06$.

143. Easterbrook \& Fischel, supra note 9, at 278.

144. O'NEAL, supra note $1, \S 9.21$ ("A particularly litigious area has been whether a partnership-like fiduciary duty prevents the termination of a shareholder/employee in a close corporation."); O’NEAL \& THOMPSON, supra note 6, § 9.07 (advising a minority shareholder to bargain for terms providing for basic salary, contingent compensation, severance pay, liquidated damages, the right to force the corporation to buy back his shares, and/or a lifetime pension); Van Vliet \& Snider, supra note 25, at 255 ("Typically, the concept of a fiduciary duty not to frustrate the reasonable expectations of a shareholder arises in a factual setting in which a shareholder's employment with the closely held corporation is terminated without cause or the balance of voting power in the corporation is disrupted.").

145. See supra note 14 and accompanying text.
} 
tial benefits to close corporation shareholders had they used the venture capital model. It also discusses potential limitations on the use of the model by typical close corporation shareholders and whether these limitations are so severe as to suggest that court-imposed fiduciary duties provide a better solution than ex ante contracting to the problems of minority shareholders.

\section{A. Applying the Venture Capital Model to Recent Close Corporation Litigation}

A few recent cases illustrate the current erratic treatment of close corporation fiduciary duties and how the use of contract terms such as those used successfully by venture capitalists could reduce the need for litigation among typical close corporation shareholders. In Kiriakides v. Atlas Food Systems \& Services, Inc. ${ }^{146}$ a minority shareholder faced a classic "freeze-out" scenario in which his brother (the majority shareholder) terminated him from his position as president, then offered him an unfairly low price for his shares. ${ }^{147}$ Operating with little legislative or case law guidance, ${ }^{148}$ the South Carolina Supreme Court ultimately determined that the majority shareholder's frustration of the plaintiff's reasonable expectations did not constitute oppression under South Carolina law. ${ }^{149}$ Thus, the minority shareholder was not entitled to a buyout of his shares on the ground that his reasonable expectations were frustrated. ${ }^{150}$ Furthermore, he received no remedy for his loss of employment or expected future income..$^{151} \mathrm{Had}$ the plaintiff emulated the venture capital model, he could have bargained for a voting arrangement that would have required him to assent to his termination, giving him greater bargaining power had he decided to leave the corporation. ${ }^{152}$ Alternatively, if this provision had been too stringent, the plaintiff might have bargained for the condi-

\footnotetext{
146. 541 S.E.2d 257 (S.C. 2001).

147. Id. at 260-61.

148. See supra note 77.

149. Kiriakides, 541 S.E.2d at 264. Numerous other states have found that frustration of the minority shareholder's expectations is grounds for dissolution or buyout. Id. at 264-66.

150. Id. at 265. Ultimately, the court did permit a buyout on the ground that the majority shareholder had engaged in otherwise fraudulent, illegal, and unfairly prejudicial conduct. Id. at

151. The trial court had ordered buyout on the ground that the minority shareholders "would receive no financial benefit [from the corporation] including salary, retirement benefits, [the plaintiff's] lack of status as President, the fact that [the plaintiff] would no longer receive loans from the company ... [and] the loss of fringe benefits." Id. at 267 n.31.

152. See supra notes $106-09$ and accompanying text.
} 268. 
tions of his termination, preventing his brother from low-balling him on his offer to purchase his shares and providing him with a future source of income. ${ }^{153}$ This arrangement would have enabled him to recover a greater amount from the corporation, sparing him the significant expense required to appeal the case through the South Carolina Supreme Court.

Kelly v. Wellsville Foundry, Inc., ${ }^{154}$ an Ohio appeals court decision, illustrates how both the majority and the minority shareholders in a close corporation could have used contract terms from the venture capital model to avoid litigation. In this case, the majority shareholder invested in a corporation with two minority shareholders who operated a competing foundry. ${ }^{155}$ Eventually, the majority shareholder sought to eliminate the minority shareholders' holdings through a reverse stock split because he feared they would use the corporation's confidential information to benefit their competing business. ${ }^{156} \mathrm{Al}$ though Ohio corporate law expressly permitted the stock split, the trial court invoked close corporation fiduciary duties to enjoin it. ${ }^{157}$ The result was not predictable, and the parties were forced to litigate through trial and appeal to reach this result. ${ }^{158}$

Both parties in this case had identifiable interests that easily might have been protected through contract. The majority shareholder knew of the minority shareholders' competing business ${ }^{159}$ and thus could have restricted their access to sensitive documents. The minority shareholders, realizing their percentage ownership was small enough to be terminated through a reverse stock split, could have secured a voting agreement requiring their votes to authorize a reverse stock split. ${ }^{160}$ Had these simple agreements been reached, no need for litigation would have arisen.

153. See supra notes $143-44$ and accompanying text. For another example of this situation, see Nelson v. Martin, 958 S.W.2d 643 (Tenn. 1997). In that case, three shareholders owned equal shares of the corporation. Id. at 644 . Two of the shareholders fired the third one. Id. The fired shareholder "acknowledge[d] that there was no written contract of employment between the corporation and him, but assert[ed] there was a general agreement among the shareholders that each was entitled to work for the corporation for life." Id. at 649.

154. No. 99-CO-27, 2000 Ohio App. LEXIS 6287 (Ohio Ct. App. Dec. 6, 2000).

155. Id. at *1-*2.

156. Id. at *16-*17.

157. Id. at *8-*15.

158. Id. at $* 1$.

159. $I d$. at $* 2$.

160. See supra notes $106-09$ and accompanying text. 
Restrictions on managerial self-dealing, such as those embodied in venture capital shareholder agreements, ${ }^{161}$ would have benefited the minority shareholders in G\&N Aircraft, Inc. v. Boehm ${ }^{162}$ and Locati v. Johnson, ${ }^{163}$ decisions from Indiana and Oregon. In G\&N Aircraft, the majority shareholder threatened to evict the corporation from its hangar space, which the majority shareholder also owned, ${ }^{164}$ and in Locati, the controlling shareholders of a close corporation gave to another corporation that they owned a ten-year exclusive license to a patent that was the close corporation's only significant asset. ${ }^{165}$ In each of these situations, the potential for managerial self-dealing was clear and easily could have been prevented with simple contractual restrictions. In $G \& N$ Aircraft, the use of cumulative dividends also could have prevented the majority shareholder's extortionate threats to block dividends for three years. ${ }^{166}$

As these examples illustrate, many close corporation problems could be resolved through ex ante reference to venture capital solutions.

\section{B. Limitations on the Application of the Venture Capital Model}

Clearly, the traditional close corporation investor has incentives to emulate the forethought of the venture capital investor, reducing the risk of "future disputes and misunderstandings." 167 Why, then, might traditional investors fail to negotiate agreements as protective as those of the venture capitalists? This Section examines some of the differences between venture capital investors and more traditional close corporation investors to assess whether the venture capital model is realistic, and it considers other factors unique to the venture capital market that may discourage litigation, even in the absence of such detailed agreements.

\footnotetext{
161. See supra notes $113-15$ and accompanying text.

162. 743 N.E.2d 227 (Ind. 2001).

163. 980 P.2d 173 (Or. Ct. App. 1999).

164. G\&N Aircraft, 743 N.E.2d at 233.

165. Locati, 980 P.2d at 174.

166. G\&N Aircraft, 743 N.E.2d at 233.

167. 1 BARTLETT, supra note $11, \S 10.1$ ("In a structured venture financing, the contract between issuer and investor is, or should be, detailed, covering a number of issues which otherwise may be the subject of future disputes and misunderstandings."). There is no reason why this same philosophy should not apply to a traditional shareholder.
} 
1. Enhanced Bargaining Power. "In venture capital, the golden rule is 'he who has the gold makes the rules.' Many venture capitalists live by this axiom. Since they are providing the cash, they expect to lay down the terms of the funding." ${ }^{, 168}$ One of the most notable attributes of the venture capital market is that the vast amount of available wealth will be bestowed upon only a few lucky entrepreneurs. ${ }^{169}$ The uncertainty of investment in a start-up is such that few are willing to accept the risks associated with it; the scarcity of supply and the magnitude of demand for risk-taking investors allows venture capitalists to exact the high price of return and control from the entrepreneurs. ${ }^{170}$ The intense competition among entrepreneurs for venture capital gives the investors a significant bargaining advantage. Thus, the negotiation of the terms of the stock purchase and shareholder agreements may represent more of a "cram down" than a true negotiation. ${ }^{171}$

168. RICHARDSON, supra note 120 , at "Golden Rule."

169. LIPMAN, supra note $15, \S 2.01$ (e), at 42 (noting that most start-ups will not pass muster for investment by venture capitalists and will be forced to seek capital from other sources); RICHARDSON, supra note 120, at "Deal Flow":

It is common for a venture capital firm to receive more than 100 business proposals each month. Therefore, it is not unusual for a venture capitalist to invest in less than one percent of the deals arriving at his doorstep. Deal flow explains ... why venture capitalists can often insist on the structure of the deals they will accept.

Smith, supra note 93 , at $89-90$ :

By contracting with managers, who are often desperate to acquire venture capital funding, venture capitalists seek concessions that allow them to exercise actual or, more frequently, potential control over management as well as constrain the activities of managers.

170. Smith, supra note 93 , at 153 :

The leverage that venture capitalists possess over management of portfolio companies means not only that they can select companies with the best management teams and impose favorable contractual provisions upon these teams, but also that they can demand a high degree of reward for their inherently risky investment. Thus, venture capital financing is often more costly than other sources of financing, with venture capitalists demanding a significant equity stake in their portfolio companies.

171. RICHARDSON, supra note 120, at "Cram Down" ("[G]rowing companies can subject themselves to an unwanted cram down by waiting too long to begin raising capital and by having no viable alternative to raising capital ... from the investor who is dictating his terms."). Another factor enhancing the investors' bargaining power is that fact that

[v]enture capital is often a financing source of "last resort." Companies that seek venture capital financing are generally left with no other alternatives for financing and are therefore in a weak bargaining position. This environment allows the venture capital investor to both select portfolio companies that the investor believes have the best possible management teams and impose contractual provisions upon the portfolio company that are favorable to the venture capital investor. Management of the portfolio company is often unable to resist these contractual demands concerning control of the company.

Smith, supra note 93 , at 152-53. 
The entrepreneur's position is weakened further by the fact that he is likely to be less experienced in legal matters and less able to afford sophisticated legal counsel than the venture capitalist. ${ }^{172}$ The entrepreneur's optimism about the success of his company also is likely to blind him to the details of the stock purchase and shareholder agreements and make him more willing to accept the terms of the proposed agreement..$^{173}$

The typical minority investor may not have the same leverage that the venture capitalist has. He may not have hundreds of proposals on his doorstep from entrepreneurs desperately seeking his investment. The amount of cash he has to invest may not be so large as to warrant his dictating the terms of his investment agreement. Thus, the typical minority investor is by no means guaranteed the ability to negotiate his desired level of control.

Although the typical close corporation minority investor may not have the same leverage as the venture capitalist, he does possess some bargaining power. "Investors in any venture are concerned about the possibility that the actions of others will reduce their return. Those who attempt to attract other people's money have incentives to adopt governance mechanisms that respond to potential investors' concerns. ${ }^{, 174}$ Even the typical close corporation investor's cash is likely to provide at least a modicum of bargaining power and he can use his bargaining power to contract for those provisions most significant to him (e.g., an employment contract or restrictions on managerial selfdealing). Other provisions that may be less important to him, such as those that deal with exit strategy, may be foregone. Additionally, the minority investor may be able to secure favorable terms by offering the majority terms favorable to it. ${ }^{175}$

2. Sophistication of Parties. Another distinction between the venture capitalist and the typical close corporation investor is the level of financial and legal sophistication possessed by the venture

172. Smith, supra note 93, at 153 ("Furthermore, managers are often hampered by the fact that venture capital investors are experienced in negotiating deals and often hire more experienced and knowledgeable legal counsel.").

173. See infra note 183 and accompanying text (describing the unrealistic optimism of close corporation participants). Other points in the agreement, such as the pre-money valuation of the company, may be sticking points for the entrepreneur, who may then overlook details about board membership and voting rights. For a definition of "pre-money valuation," see RICHARDSON, supra note 120, at "Pre-Money Valuation."

174. Easterbrook \& Fischel, supra note 9, at 277.

175. See supra notes 154-60 and accompanying text. 
capitalist. Many venture capitalists qualify as "accredited investors" under the Securities Act, ${ }^{176}$ "persons or entities which are recognized by the statutes as having sufficient wealth, sophistication (or access to sophisticated advice), and access to company information to fend for themselves when examining and investing in a privately held company." ${ }^{177}$ Most have the financial resources to obtain the highest quality of legal and financial assistance, and they often discourage the entrepreneurs from obtaining their own legal counsel. ${ }^{178}$ They are veterans of the business world, often with tremendous experience in the acquisition of their own fortune. ${ }^{179}$ Prior to reading a business plan, they usually have no relationship to an entrepreneur. ${ }^{180}$

In contrast, "[p]articipants in closely held corporations frequently have familial or other personal relations in addition to their business dealings." 181 These personal relationships reduce the formality of the parties' dealings, increasing the risk that they will not foresee irreconcilable disputes that ex ante contracting could prevent. ${ }^{182}$ Because of these prior relationships, close corporation participants also fail to consider the possibility of business failure and "demonstrate an overly optimistic trust in their co-venturers." ${ }^{\text {"183 }}$ Many times their business may have operated in an unincorporated form, and the participants assume the existing power structure will continue once the business is incorporated. ${ }^{184}$ The typical investor also may not have the financial resources or incentives to seek out sophisticated legal assistance, preferring to take his chances with the word of the other participants. This may be his first investment in a corporation, and he

\footnotetext{
176. 15 U.S.C. § 77b(15)(ii) (1994).

177. RICHARDSON, supra note 120, at "Investors"; see LIPMAN, supra note 15, § 6.04, at 176 (presenting a provision of a venture capital agreement attesting to the experience of the investors).

178. RICHARDSON, supra note 120, at "Lawyers."

179. Id. at "Adventure Capitalists."

180. See supra note 169 (describing the enormous number of plans the typical venture capitalist encounters).

181. Easterbrook \& Fischel, supra note 9, at 274; see supra notes 22-23 and accompanying text.

182. O'NEAL, supra note $1, \S 1.21$. Although this lack of foresight is one effect of close relationships among close corporation investors, another effect is that the "continuous and nonpecuniary nature of these relationships reduces agency problems. The bond between parents and children, for example, constrains conflicts of interest." Easterbrook \& Fischel, supra note 9, at 274.

183. O'NeAL \& THOMPSON, supra note $6, \S 9.18$.

184. See, e.g., Kiriakides v. Atlas Food Sys. \& Servs., Inc., 541 S.E.2d 257, $260-61$ (S.C. 2001) (describing the incorporation of a family-operated business and its subsequent development, leading up to the termination of one of the brothers from his position as president).
} 
may know little about the financial or legal circumstances surrounding his investment. Thus, unlike the venture capitalist, he is unable to anticipate threats to his investment or participation in the corporation and thus is unlikely to contract to protect them.

Imposition of ex post fiduciary duties does not necessarily remedy this problem, however, because it may discourage the close corporation shareholder from investing in ex ante contracting. Because the law is somewhat unpredictable, the minority investor may rely to his detriment on the hope of a judicial remedy.

3. Inherent Riskiness of Investment and Greater Investment in Negotiation. The risk associated with a traditional close corporation investment is inherently less than the risk a venture capitalist assumes when investing in a high-growth start-up. ${ }^{185}$ Because their investments entail so much risk, "the venture capitalist may be willing to absorb higher-than-average transaction costs in attempting to realize the large amount of gain inherent in risky venture capital endeavors."

Venture capitalists' investments are risky because the investments lack liquidity and because the venture capitalist is less able to diversify. ${ }^{187}$ Also, venture capitalists invest in companies whose financial feasibility is inherently unknowable and expensive to investigate. ${ }^{188}$ This uncertainty gives the venture capitalists the leverage to negotiate the terms of their investment agreements and the incentive to spend substantial amounts of money on negotiation costs.

\footnotetext{
185. 1 BARTLETT, supra note $11, \S 1.3$ :
}

Every start-up does not dance to the venture capital tune. Hundreds of thousands of new enterprises are originated every year for reasons having nothing to do with a venture play, that is, grocery stores, filling stations, suburban construction companies, truck farms-conventional businesses organized by an entrepreneur who feels that his skill and experience can be employed more profitably on his own. The object of such business organizations is to provide an income for the organizers and perhaps members of their families; if the business takes hold, it can be a legacy for the founders' children .... This category of endeavor has acquired the somewhat pejorative label (because it is often family oriented) of the "mom and pop" business.

Smith, supra note 93, at 150 ("Venture capitalists often seek an extremely high rate of return on their investments. The investments that they make often involve a correspondingly high degree of risk.").

186. Smith, supra note 93 , at 150 .

187. Id. at 151 .

188. Id. at 151-52 ("The costs of gathering information may be particularly great in start-up companies that lack an extensive track record or in small companies. These are precisely the types of businesses in which venture capitalists generally invest. Therefore, large information costs may be inherent in the nature of the business."). 
Like the venture capitalist, the typical close corporation investor faces the risk posed by the illiquidity of his shares, although other types of risk, such as the risk of investing in a new technology, are not present. This indicates that the venture capital model is unlikely to be utilized fully by the typical close corporation investor. With a lower risk of business failure, the close corporation investor may decide consciously or unconsciously that the expense of negotiating a detailed contract is not justified. From an economics approach, this can be a fully rational decision, as long as the investor has identified fully the risks at stake, both in terms of the financial success of the business and in terms of his own risk of freeze-out. If an investor makes a rational decision that the expense of a negotiation is not worth the protection he might receive from it, a court arguably should respect that decision, thus inducing parties to invest in the optimal amount of preinvestment research and negotiation.

This distinction is particularly noticeable with regard to exit strategies. In a regular close corporation, " $\mathrm{t}]$ here is no 'exit strategy,' no expectation of a dynamic multiple of earnings being paid for the business five years down the road." ${ }^{189}$ Many traditional close corporation investors anticipate that they may be permanently employed by the corporation, that this is now their livelihood, not merely a brief endeavor that will result in a public offering and their exit. Conversely, the venture capitalist is typically not interested in a permanent relationship with the corporation. ${ }^{190}$

This emphasis on cashing out prompts the venture capitalist to negotiate for as many exit avenues as possible. ${ }^{191}$ Although contemplating the potential need for exit would be a very wise thing for a traditional close corporation investor to do, even if she believed she wanted to work permanently for the corporation, her expectations at the outset usually make this less of a sticking point in the negotiation process. ${ }^{192}$ An economics approach to this situation would yield an analysis similar to the analysis of how risk affects the investment in research and negotiation. An investor should not use up all of her bargaining chips negotiating for exit avenues if she does not anticipate wanting to exit the corporation. However, the venture capital

189. 1 BARTLETT, supra note $11, \S 1.3$.

190. LIPMAN, supra note $15, \S 2.01$ (f), at 44 ("All investors in privately-held companies want an 'exit strategy,' that is, a method of ultimately cashing-in on their investment.").

191. Smith, supra note 14, at 142 ("Venture capitalists typically strive to preserve a menu of potential exit strategies.").

192. See supra note 17 and accompanying text. 
agreement is a useful tool in considering legislative possibilities for mutable default rules that provide exit options for minority shareholders. Although many jurisdictions now have buyout and dissolution provisions, ${ }^{193}$ default drag-along and tag-along provisions also may vastly improve the lot of the minority shareholder and result in the preservation of the corporation and the avoidance of litigation that the buyout and dissolution provisions do not provide. ${ }^{194}$

\section{Distinctions Between the Venture Capital World and the Tra-} ditional Close Corporation World that May Influence the Amount of Litigation. In addition to the agreements utilized by venture capitalists, other factors unique to the venture capital world also may influence the lack of litigation resulting from that type of investment. Although it is difficult to determine the extent of the influence of these factors on the incentive to litigate, they likely exert some influence, weakening the argument that the venture capital model will reduce litigation in traditional close corporations.

One trait common to venture capital investments is stage financing, where the investor commits more money to the corporation only if the corporation achieves certain successes defined by the investor. ${ }^{195}$ This stick-and-carrot approach ensures the entrepreneurs' compliance with the investors' wishes, less because they are bound contractually to do so and more because they are bound financially if they want to keep the dream of their company's success alive. ${ }^{196}$

Unlike the cash-cow investors in the venture capital market, the average close corporation investor likely does not have the funds to engage in stage financing, which by most accounts is a weighty factor in keeping disputes among investors and entrepreneurs to a mini-

\footnotetext{
193. O'NEAL \& THOMPSON, supra note $6, \S 9.30$.

194. See supra notes 129-37 and accompanying text.

195. RICHARDSON, supra note 120, at "Stage Financing."

196. 1 BARTLETT, supra note $11, \S 9.2$ (noting that although the investors take great pains to ensure some measure of contractual control over the enterprise, "[t]he real power the investor group has over a cash-poor corporation is economic, not legal; the investors are the only source of fresh funds to keep doors open. No law requires an investor group to advance fresh money ... so the power of the purse rests with the investors."). In the typical "milestone" or "benchmark" deal,

[t]he investors parcel out the committed sums if and only if the founder is able to pass stated tests by specific dates. If the dates are missed, the founder is penalized by (1) failing to be able to call down the later installment, (2) coughing up additional equity, or (3) a combination of the two.... [M] any venture financings are in fact, if not in name, of the "milestone" variety.

Id. $\S 10.2$.
} 
mum. ${ }^{197}$ Because venture capitalists have so much money compared with most other close corporation investors, ${ }^{198}$ it is unlikely that the effects of stage financing can be replicated in the general close corporation universe.

Another factor affecting participants in venture capital investments is the intense scrutiny of the reputation of both investors and entrepreneurs that occurs prior to a deal. Because entrepreneurs desperately are seeking cash and because venture capitalists are competing with each other to invest in the few meritorious enterprises they find, both parties worry about their own reputations for fair dealing. ${ }^{199}$ This concern encourages both parties to resolve disputes without litigation; litigation sounds a warning bell to the rest of the community. ${ }^{200}$

Unlike the effects of stage financing, the effects of reputation may not discourage litigation in the venture capital context more than they do in the ordinary close corporation context. Few corporations would want to deal with litigious investors, and the close relationships of friendship or family are a good substitute for investigation of the

197. Id. § 9.2; see infra note 200.

198. See supra notes $178-80$ and accompanying text.

199. See Smith, supra note 14, at 142 ("[T] he only apparent check on [venture capital opportunism] is the venture capitalists' fear of reputational backlash.").

200. RiCHARDSON, supra note 120, at "Ethics":

Even if [a company could sue its investor to force it to fund], the actions required to do so would be a serious drain on the company and might frighten other investors away. After all, how many investors want to put money into a company that is suing its prior investor?

Because venture capital agreements tend to give a great deal of power to the investors, entrepreneurs are well advised to consider the ethical reputation of their investors as well, and to choose them wisely. Id:

Investors recognize the need to deal only with people they can trust. . . Entrepreneurs should be just as careful to examine their investors' reputations. . . The best way to avoid these problems is to be careful when selecting investors, to investigate their reputations, and to try, when possible, to deal only with people who are trustworthy.

As information regarding investors becomes more widespread, particularly through forums such as the Internet, entrepreneur scrutinization of investors likely will become even more intense. Even now, "[m]ost venture capitalists rely heavily on reputation ('brand name') to assure entrepreneurs regarding the quality of future services they are "purchasing." Smith, supra note 14, at 143. As a result of the emphasis on reputation in choosing both investors and investments, "entrepreneurs are loath to sue their venture capitalists for fear of gaining a reputation for recalcitrance and never receiving venture funding. On the other hand, venture capitalists are reluctant to sue entrepreneurs because they fear acquiring a reputation for abusiveness that will drive away future entrepreneurs." Id. at 153. 
investors' reputation and similarly deter extortionate behavior. ${ }^{201}$ Thus, the smaller size of the venture capital community and its quirky disdain for litigation may be only slightly greater forces in deterring litigation, if at all.

\section{Implications}

Even those who believe that the shareholder-fiduciary rule is the best solution to the problems of close corporations acknowledge that "its progress has been uncertain and incomplete, as might be expected for a rule evolving by the case decision process." ${ }^{202}$ Although disparities between venture capital investors and typical close corporation investors certainly exist, ${ }^{203}$ many are less extreme than they appear at first blush, and many are consistent with an economic, contractarian approach to close corporations. For instance, the greater investment made by venture capitalists in response to the riskiness of their investments and the enhanced bargaining power that enables venture capitalists to gain more control over their portfolio companies do not lessen the applicability of the venture capital model to a close corporation investor; these factors merely weaken the form in which the typical close corporation investor may utilize the model. ${ }^{204}$ An investor with less bargaining power or facing a less risky investment thus may rationally choose to negotiate based on a weaker form of the venture capital model, focusing on those provisions of most significance to him. This is consistent with Easterbrook and Fischel's argument that "[b]ecause people select the organizational device in which to invest, at the margin the risk-adjusted returns must be the same." 205

Given the venture capital model's efficacy in minimizing litigation, ${ }^{206}$ courts and legislatures alike should consider its success when

201. O’NEAL, supra note $1, \S 1.08$ :

[S] hareholders in a close corporation commonly are greatly concerned about the identity of their associates and have a strong desire to gain and hold the power to choose future shareholders or at least to veto prospective purchasers of shares whom they consider undesirable. They are reluctant to run the risk of having the harmony and balance of their business organization disturbed or the mutual respect and confidence of the shareholders-managers shattered ....

202. Van Vliet \& Snider, supra note 25 , at 239.

203. See supra notes 167-201 and accompanying text.

204. See supra notes 167-201 and accompanying text.

205. Easterbrook and Fischel, supra note 9, at 301.

206. See supra note 14 and accompanying text. 
further developing the law of close corporations. Its success supports at least two directions close corporation law might take.

One direction would suggest that despite the differences between venture capitalists and traditional close corporation investors, the success of the venture capital model buttresses the notion that ex ante contracting can eliminate the need for the smorgasbord of ex post judicial remedies currently in use. Based on this premise, legislatures should enact mutable default provisions that mimic venture capital agreements. ${ }^{207}$ This solution provides the certainty of result that O'Neal's recommendation, legislation "to protect the reasonable expectations of persons acquiring an interest in a close corporation," ${ }^{208}$ does not. The benefits of such a rule (i.e., empowering minority investors) thereby are preserved without the problems of judicially crafted solutions; even if parties do not choose to enact such provisions, they will have to actively contract around them, increasing the likelihood that parties will invest more forethought in the investment contract, counteracting the effects of some investors' lack of sophistication. ${ }^{209}$ Default provisions that favor the minority investor will reduce the disparity in bargaining power and thus achieve a balance between the parties resembling the balance between venture capitalists and entrepreneurs. At a minimum, legislatures should provide for the creation of form agreements that would alert a less sophisticated lawyer to potential contract terms that a minority shareholder would benefit from in negotiating an investment in a close corporation.

A second and decidedly harsher direction close corporation law might take would rely on the success of the venture capital model to argue that ex post fiduciary remedies and default provisions favoring minority investors are both unnecessary. The venture capital model proves that close corporation laws that permit freedom of contract but generally do not impose additional fiduciary duties for close corporation shareholders clearly meet the needs of certain closely held corporations. ${ }^{210}$ Those whose needs it does not meet should be herded

\footnotetext{
207. O'NEAL, supra note $1, \S 1.21$.

208. Id. §1.21(5).

209. Id. § 1.21(4) (making a few recommendations for statutory defaults).

210. Bartlett notes that many corporations receiving venture capital investment do not even elect close corporation status because "the law applicable to these entities is not fully developed, entailing uncertainty; the shareholders may be exposing themselves to liability if they exercise directorial control." 1 BARTLETT, supra note $11, \S 4.7$. This fear supports the position that close corporation law should serve a role that eliminates the problems of applying general corporate law but should not impose partnership-like fiduciary duties, thereby scaring off those who would be the intended beneficiaries of special close corporation provisions.
} 
toward organizational forms that better suit their needs. ${ }^{211}$ Although this route initially may produce a few harsh results, it eventually will prove beneficial by encouraging the proper choice of organizational form and thereby reducing the amount of litigation for all parties. ${ }^{212}$

Whatever the desirability of these directions, the success of the venture capital model at least partially refutes the argument that:

Because the shareholder-fiduciary rule is beneficial in its purpose, it should be fostered rather than curbed. Where legislative action is proposed for closely held corporations, it should be directed at improving or completing the development of the rule, rather than destroying it, as was proposed in Illinois. The special needs of closely held corporations derive from the special nature of those corporations, a fact so often mentioned in the authorities and so frequently ignored by the critics of the rule. The shareholder-fiduciary rule is by no means a finished or perfect concept. Further evolution and improvement by case decision or legislation, or both, will be needed. ${ }^{213}$

The venture capital example proves that certain close corporations not only do not need enhanced fiduciary duties imposed but also disdain the unpredictability of their imposition. ${ }^{214}$ Instead of using law to enhance the application of fiduciary duties, the law should supply default terms that mimic those of the venture capital agreement to equalize the ex ante bargaining power of the majority and minority shareholders. As a weaker alternative, standard form contracts should be used to fill the informational gap and to enhance minority shareholder awareness (and lawyer awareness) of the type of provisions they should negotiate. Narrowing the sophistication gap between the typical close corporation shareholder and the venture capitalist will

211. Wortman, supra note 8, at 1396-407 (explaining the advantages of LLC statutes over close corporation statutes). See generally VGS, Inc. v. Castiel, No. C.A. 17995, 2000 WL 1277372 (Del. Ch. Aug. 31, 2000) (illustrating the freedom of contract and partner-like fiduciary duties available to LLCs).

212. For a comprehensive discussion of the wisdom and selection of penalty default rules, see generally Ian Ayres \& Robert Gertner, Filling Gaps in Incomplete Contracts: An Economic Theory of Default Rules, 99 YALE L.J. 87 (1989).

213. Van Vliet \& Snider, supra note 25 , at 264.

214. 1 BARTLETT, supra note $11, \S 4.7$; J. William Callison, Venture Capital and Corporate Governance: Evolving the Limited Liability Company to Finance Entrepreneurial Business, $26 \mathrm{~J}$. CORP. L. 97, 111 (2000) (arguing that LLCs have not attracted venture capital investment because they "do not provide efficient separation between ownership and management control"); $i d$. at 113 (explaining that venture capitalists do not want to be managers in LLCs because they do not want to assume fiduciary duties). 
reduce the need for ex post fiduciary duties, as well as stabilize and make more predictable the law of close corporations.

\section{CONCLUSION}

A quarter of a century after the first state applied enhanced fiduciary duties to close corporation minority shareholders, the law still provides extremely limited guidance as to the standards of acceptable conduct by close corporation shareholders. During this time, venture capitalists assuming minority investor roles in close corporations have proved that freedom of contract alone can eliminate the inequitable results often created by the application of general corporate law to close corporations. Based on this example, courts should be less reluctant to enforce the explicit agreements of shareholders and should shy away from prolonging the inconsistent, post hoc development of close corporation shareholder duties. Coupled with the development of highly viable alternative forms of firm organization, this result will ensure that those entities that prefer the law of corporations will be assured of the application of that law and that those that prefer the protection of partnership-like fiduciary duties will organize in forms that provide that protection, creating predictable results for both types of closely held company. 